\title{
Effect of Chemical-Hydrothermal Pretreatments on Compositional and Morphological Changes of Spruce Wood Exploited in Biogas Systems
}

Fatemeh Rahimi-Ajdadi ( $\square$ rahimi_a61@yahoo.com )

University of Guilan https://orcid.org/0000-0002-3547-0403

Masoomeh Esmaili

Laboratory of Physical Chemistry, Department of Chemistry, Faculty of Sciences

\section{Research}

Keywords: Biofuel, Combined pretreatment, Lignin removal, Phenol, SEM analysis

Posted Date: April 23rd, 2020

DOI: https://doi.org/10.21203/rs.3.rs-22584/v1

License: (c) (1) This work is licensed under a Creative Commons Attribution 4.0 International License.

Read Full License 


\section{Abstract}

Agricultural crops and forest residues are of valuable resources to produce biofuel due to anaerobic digestion. But, the recalcitrance nature of these lignocellulose residues limits its enzymatic degradation and decreases biogas production. Therefore, efficient pretreatments prior to anaerobic digestion are essential. In present study, hydrothermal-chemical pretreatments using Phenol (Ph), Sodium Hydroxide (SH) and Phosphoric Acid (PA), and combined pretreatments included $\mathrm{Ph}+\mathrm{SH}$ and $\mathrm{Ph}+\mathrm{PA}$ as chemical pretreatments were used for spruce wood. For hydrothermal pretreatments, the samples were put into the autoclave at $134{ }^{\circ} \mathrm{C}$ for $20 \mathrm{~min}$. Acid hydrolysis, FTIR and SEM analyses were carried out. The results indicated that all pretreatments were effective lignin removal having the highest value for $\mathrm{Ph}(42.362 \%)$. Adding $\mathrm{Ph}$ to PA, caused to increase lignin removal from 1.580-6.112\%. Mixing $\mathrm{Ph}$ to $\mathrm{SH}$ represented the same trend in changing structure of spruce wood as compared to individually use of $\mathrm{SH}$. All results proposed that when $\mathrm{Ph}$ contributed in binary pretreatment with $\mathrm{SH}$ and PA, it could be more effective on the morphological changes of spruce wood. In general, $\mathrm{Ph}$ was more effective on changing the crystalline structure of spruce wood than the others. After that, $\mathrm{Ph}+\mathrm{SH}$ was more effective compared to $\mathrm{Ph}+\mathrm{PA}$ on structural changes of spruce wood. In comparison between alkali and acidic pretreatments, SH represented more structural change in spruce wood than PA one. To have an intermediate state, it is recommended to use the combination of $\mathrm{Ph}$ with $\mathrm{SH}$ as infectious pretreatment instead of individually $\mathrm{Ph}$. Because, this increases the biodegradation power of $\mathrm{SH}$ while the toxicity of $\mathrm{Ph}$ decreases. The obtained results are very important in biogas production systems.

\section{Introduction}

With appearing new technological advancements particularly in developing countries, energy demands are continuously growing up. Currently, the world's largest source of energy is fossil fuels which have some disadvantages such as resource limitation, rising prices and environmental pollution. Accordingly, many attentions have been concentrated in the world to access alternative energy sources which are both economically and environmentally acceptable (Zilouei and Taherdanak, 2015). Among different types of renewable energy resources, bioenergy plays an important role as fourth largest energy resource in the world (Rajput and Visvanathan, 2018). So far, three generations of biofuels have been introduced around the world, including: edible parts of plants, non-edible parts of plants and microalgae. Among these three generations, the second one, especially the lignocellulose biomass, is of the greatest interest, due to lack of human nutritional value, low cost and abundance of resources. In addition, by converting these materials into fuel, the large amount of agricultural and forest residues produced annually, could be managed. It is noteworthy, in most developing countries, such residues are burnt by farmers inside the farm, which in turn causes environmental risks through greenhouse emissions. Lignocellulose materials such as stems and crop residues, forest residues and energy crops are common organic materials that have great potential for biogas production (Celiktas et al. 2014; Chen et al. 2014; Taherdanak et al. 2016). Biogas extracted from lignocellulose biomass provided that could be produced by anaerobic digestion and properly recovered, capable of achieving sustainable energy functions without contaminating the 
environment (Chojnacka et al. 2015). In the other words, anaerobic digestion is an environmentally friendly technology for the production and recovery of degradable organic wastes (Venturin et al. 2019). But, there is one major limitation in the degradation phase of such materials. The primary chemical composition of lignocellulose biomass consists of three types of polymers called cellulose, hemicellulose and lignin. Cellulose is the major component of biomass and many cellulose properties depend on the crystalline chain properties or its degree of polymerization (Monlau et al. 2013). The previous studies showed that decrease the crystallinity causes to increase the accessibility of cellulose to enzymatic attack and improve the yield of subsequent enzymatic hydrolysis (Mirahmadi et al. 2010). Hemicelluloses are present in almost all plant cell walls with cellulose (Per 1993), which binds between lignin and cellulose fibers. Short side chains containing different sugars can be easily hydrolyzed (Nimz 1984). Lignin is the most abundant polymer in nature after cellulose and hemicellulose (Liqian 2011) and creates a strong mechanical layer for plants (Dollhofer et al. 2018). Lignin has a very strong binding to cellulose and hemicellulose and it is very difficult to break down. Holocelluloses (cellulose and hemicellulose) can decompose to methane by anaerobic germs (Chen et al. 2014), but lignin is hydrophobic and resistant to attack by germs. Therefore, it reduces the availability of holocellulose to anaerobic microbes and so limits its rate of degradation (Rajput and Visvanathan 2018) and results lower biogas performance.

The available solution is to select and apply effective pre-treatments prior to anaerobic digestion in order to break the bond between polysaccharides and lignin. This allows more cellulose and hemicellulose access to the bacterium (He et al. 2008). Various pretreatment methods have been introduced to increase the anaerobic digestibility of lignocellulose biomass including physical, mechanical, chemical, biological and hybrid methods. Appropriate pretreatment assignment is one of the most important steps to increase digestibility and biogas production for a special substrate. Because, the relative amounts of lignocellulose compounds are different in different types of agricultural biomass. On the other hand, due to the high variability of pretreatments results, depending on biomass type, the same pretreatment need to be tested on other lignocellulose biomass with different chemical and structural composition (Sambusiti 2013). However, many researchers have studied on optimal pretreatments for lignocellulose materials, more research is still needed to find the optimal conditions for applying different pretreatments. According to the aforementioned, the present study investigates the effect of different chemicals on the amount of de-lignin process and structural changes of spruce wood waste that is one of the largest forest wastes. The main innovation of the present study is to investigate Hybrid pretreatments for lignocellulose biomass instead of individual one. In other words, the present study surveys whether the hybrid pretreatments could be effective in increasing lignin removal, structural changes or reducing crystallization.

\section{Material And Methods}

\section{Raw material and pretreatments}


The raw material used as lignocellulose biomass was spruce wood from forest residues. These materials were made from milled wood waste used in the wood industry. Therefore, the first pretreatment applied to this material was mechanical grinding and size reduction, which were screened through meshes with $2 \mathrm{~mm}$ diameter to equalize their size.

The chemical pretreatments used in the study were Phenol (Ph), Sodium Hydroxide (SH), Phosphoric Acid $(\mathrm{PA})$, and binary pretreatments included $\mathrm{Ph}+\mathrm{SH}$ and $\mathrm{Ph}+\mathrm{PA}$. Each sample of milled wood $(20 \mathrm{~g})$ were pretreated with $100 \mathrm{ml}(1 \% \mathrm{v} / \mathrm{v})$ of these solutions. The prepared mixtures were kept at ambient temperature $\left(26^{\circ} \mathrm{C}\right)$ for $30 \mathrm{~min}$, then transferred to an autoclave. The samples were put into the autoclave at $134{ }^{\circ} \mathrm{C}$ for $20 \mathrm{~min}$. Afterwards, the samples were get out the autoclave and cooled to the room temperature. Then, the samples were washed with distilled water for several times to neutralize them. They were placed into an oven at temperature of $105^{\circ} \mathrm{C}$ for $24 \mathrm{~h}$. The samples were stored at $4{ }^{\circ} \mathrm{C}$ in the refrigerator for subsequent analysis.

\section{Experimental Analysis}

Wood lignin was analyzed using NREL standard method (Ehrman 1994; Mirahmadi et al. 2010), in which acid hydrolysis of cellulose and hemicellulose were used to break down the sugar polymers into sugarforming units. Acid insoluble lignin content was determined by weight changes before and after acid hydrolysis. The percent of lignin removal was calculated according to Eq. 1 (Gao et al. 2014).

$$
\begin{aligned}
& \text { Ligninremoval }(\%)=1-\frac{\% \text { Lignininsolidafteronestepacidhydrolysis }}{\% \text { Lignininrawbiomass }} \times \text { Solidyield }(1) \\
& \text { Lignin removal }(\%)=1-\frac{\% \text { Lignin in solid after one step acid hydrolysis }}{\% \text { Lignin in raw biomass }} \times \text { Solid yield } \quad \text { (1) }
\end{aligned}
$$

The amount of acid soluble lignin was also calculated by UV-Vis spectroscopy and its absorption intensity at $205 \mathrm{~nm}$. The surface chemistry of the treated and untreated woods was determined using Fourier Transform Infrared spectrometer (FTIR) (JASCO 4700, International Co). In this method, the absorption spectra of treated and untreated woods ranging from 500 to $4000 \mathrm{~cm}^{-1}$ were investigated. The crystallinity was determined by three methods including Cross-Linked Lignin ratio (CLL), Lateral Order Index (LOI) and Hydrogen Bond Intensity (HBI). The cross-linked structure is a characteristic feature of the concentration in guaiacyl. To evaluate the proportion of lignin with condensed and cross-linked structures (CLL), the ratio between band intensities at 1600 and $1508 \mathrm{~cm}^{-1}$ were calculated (Auxenfans et al. 2017; Mann et al. 2009).

The ratio of $1427 / 897$ was used to estimate LOI (correspond to a $\mathrm{CH}_{2}$ bending vibrations) (Khedkar et al. 2018) which is related to the amount of the crystalline structure of cellulose (Nelson and O'Connor 1964). $\mathrm{HBI}$ is calculated from the ratio of intensities at $3400 \mathrm{~cm}^{-1}(\mathrm{O}-\mathrm{H}$ stretching, $\mathrm{H}$-bonds between molecules) 
and $1320 \mathrm{~cm}^{-1}$ ( $\mathrm{CH}$ rocking vibration of the glucose ring). It is defined the degree of intermolecular regularity, i.e. crystallinity as well as the amount of bound water (Auxenfans et al. 2017; Oh et al. 2005).

In order to evaluate the influence of pretreatment on the morphology of wood, Scanning Electron Microscopy analysis (SEM) was performed using a high resolution SEM FEI Quanta 200. The dry material was coated a thin layer of gold.

\section{Results And Discussion}

In present study, the combined hydrothermal-chemical pretreatments were used for increasing lignin removal and accelerating the process of sugars digestion and the biogas production which are done by microorganisms. The chemical solutions used were $\mathrm{SH}, \mathrm{PA}, \mathrm{Ph}, \mathrm{Ph}+\mathrm{SH}$ and $\mathrm{Ph}+\mathrm{PA}$ solutions that their effects on chemical structure of spruce wood were investigated.

\section{Effect Of Pretreatments On Composition Of Spruce Wood}

The amounts of lignin content for treated and untreated spruce woods are summarized in Table 1. As observed, Acid Insoluble Lignin (AIL) with $30.366 \%$ is the main part of lignin in spruce wood. The amount of AlL increased after using all of applied pretreatments, with the lowest and highest values for PA (31.756\%) and $\mathrm{Ph}(48.878 \%)$ solutions, respectively. Acid Soluble Lignin (ASL) decreased by $\mathrm{SH}, \mathrm{Ph}$ and $\mathrm{SH}+\mathrm{Ph}$ pretreatments and increased by PA and PA + Ph pretreatments (Table 1). Forasmuch as reduction in lignin content is a key outcome of an efficient pretreatment (Hendriks and Zeeman 2009), lignin removal was calculated for each solution in order to more clarify (Table 1).

Table 1

The amounts of lignin content for treated and untreated spruce woods

\begin{tabular}{|llll|}
\hline Solution type & ASL (\%) & AlL (\%) & Lignin removal (\%) \\
\hline Ph & 0.475 & 48.878 & 42.362 \\
\hline SH & 0.493 & 35.364 & 12.487 \\
\hline Ph + SH & 0.480 & 34.645 & 10.186 \\
\hline PA & 0.559 & 31.756 & 1.580 \\
\hline Ph + PA & 0.551 & 33.345 & 6.112 \\
\hline Untreated & 0.530 & 30.366 & - \\
\hline
\end{tabular}

According Table 1, all of the pretreatments positively affected the lignin removal and their variation range was between $1.580(\mathrm{PA})$ and $42.362 \%(\mathrm{Ph})$. As can be deduced, the effect of PA solution on lignin removal alone was not too much (1.580\%). But, combining two solutions of PA and Ph, caused to enhance their effect on lignin removal up to $6.112 \%$. This demonstrates that adding Ph solution improves 
the performance of PA in terms of lignin removal. However, addition of Ph to SH lead to the opposite results so that the lignin removal slightly decreased. As observed, among the studied pretreatments, the effect of Ph on lignin removal was more than the others.

It should be mentioned that most studies performed on lignocellulose materials attempted to focus on the pretreatments which could accelerate the hydrolysis of cellulosic parts and break the bonds between the sugars. Reason for ignoring lignin removal is that lignin content in lignocellulose materials generally could not be effectively removed in those studies. The results obtained from present study indicate the good effect of the selected pretreatments on lignin removal of spruce wood. In a research studied on spruce wood by Mirahmadi et al. (2010), it was approximately observed no destruction of lignin content using $\mathrm{SH}$ pretreatment in mild condition, while SH pretreatment in present study could remove lignin up to $12.487 \%$.

The closely research with present study performed by Mohsenzadeh et al. (2012) who investigated the effect of alkali pretreatment on spruce woods. Their lignin removals were between 11.1 and $23.4 \%$ in all of used pretreatments. In their research, the highest value of lignin removal was obtained for mixing SH with Polyethylene glycol at temperature of $22^{\circ} \mathrm{C}$. While the highest lignin removal of $42.362 \%$ was obtained using $\mathrm{Ph}$ pretreatment in present research.

\section{Compositional And Morphological Analysis}

Using FTIR spectroscopic technique, the changes in hemicellulose and cellulose structures before and after the pretreatments were investigated. Table 2 shows the FTIR peaks for the following samples: untreated spruce wood, $\mathrm{Ph}, \mathrm{SH}, \mathrm{SH}+\mathrm{Ph}, \mathrm{PA}$, and PA + Ph. FTIR spectra of untreated wood shows a band at $897 \mathrm{~cm}^{-1}$, which represent $\beta-(1-4)$ glycosidic linkages of cellulose and it is attributed to amorphous cellulose. For all treated spruce woods compared to the untreated, absorbance of amorphous cellulose has increased, except $\mathrm{Ph}$. However, the absorbance is higher for $\mathrm{SH}$ and $\mathrm{PA}+\mathrm{Ph}$ pretreatments compared to $\mathrm{SH}+\mathrm{Ph}$ and $\mathrm{PA}$. This data proposes maximum structure changed and enhancement of cellulose content for SH and PA + Ph treatments (Khedkar et al. 2018; Pal et al. 2016). According to the previous study by Li et al. (2016) on M. Iutarioriparius samples, steam explosion increased peak intensity at $897 \mathrm{~cm}^{-1}$ and also they suggested the augmentation of cellulose content after pretreatment. This is consistent with results of the current study. 
Table 2

Assignments of FTIR spectrum with relative band intensity absorption for studied pretreatments

\begin{tabular}{|c|c|c|c|c|c|c|c|c|}
\hline \multirow{2}{*}{$\begin{array}{l}\text { Band } \\
\text { no. }\end{array}$} & \multirow{2}{*}{$\begin{array}{l}\text { Band } \\
\text { Region in } \\
\text { Wave } \\
\text { number } \\
\left(\mathrm{cm}^{-1}\right)\end{array}$} & \multirow[t]{2}{*}{ Assignments } & \multicolumn{6}{|c|}{ Relative absorbance } \\
\hline & & & Untreated & $\mathrm{Ph}$ & SH & $\begin{array}{l}\mathrm{SH}+ \\
\mathrm{Ph}\end{array}$ & PA & $\begin{array}{l}\mathrm{PA}+ \\
\mathrm{Ph}\end{array}$ \\
\hline 1 & $\sim 835$ & $\begin{array}{l}\text { C-H out of plane } \\
\text { vibration in lignin }\end{array}$ & 0.010 & 0.008 & 0.018 & 0.015 & 0.014 & 0.020 \\
\hline 2 & $\sim 897$ & $\begin{array}{l}\mathrm{C}-\mathrm{H} \text { deformation in } \\
\text { cellulose }\end{array}$ & 0.011 & 0.009 & 0.023 & 0.017 & 0.018 & 0.021 \\
\hline 3 & $\begin{array}{l}1040- \\
1060\end{array}$ & $\begin{array}{l}\text { C-O stretch in } \\
\text { cellulose and } \\
\text { hemicellulose }\end{array}$ & 0.037 & 0.031 & 0.066 & 0.039 & 0.060 & 0.055 \\
\hline 4 & $\begin{array}{l}1160- \\
1170\end{array}$ & $\begin{array}{l}\text { C-O-C vibration in } \\
\text { cellulose and } \\
\text { hemicellulose }\end{array}$ & 0.013 & 0.011 & 0.026 & 0.018 & 0.022 & 0.026 \\
\hline 5 & $\begin{array}{l}1240- \\
1260\end{array}$ & $\begin{array}{l}\text { Guaiacyl ring } \\
\text { breathing, C-O stretch } \\
\text { in lignin }\end{array}$ & 0.014 & 0.011 & 0.016 & 0.014 & 0.020 & 0.024 \\
\hline 6 & $\begin{array}{l}1320- \\
1330\end{array}$ & $\begin{array}{l}\text { Syringyl ring } \\
\text { breathing in lignin }\end{array}$ & 0.009 & 0.007 & 0.019 & 0.015 & 0.015 & 0.020 \\
\hline 7 & $\begin{array}{l}1370- \\
1380\end{array}$ & $\begin{array}{l}\mathrm{C}-\mathrm{H} \text { deformation in } \\
\text { cellulose and } \\
\text { hemicellulose }\end{array}$ & 0.008 & 0.006 & 0.015 & 0.012 & 0.013 & 0.020 \\
\hline 8 & $\begin{array}{l}1420- \\
1430\end{array}$ & $\begin{array}{l}\text { Aromatic skeleton } \\
\text { vibration (methyl) in } \\
\text { lignin combined with } \\
\mathrm{C}-\mathrm{H} \text { plane } \\
\text { deformation in } \\
\text { carbohydrates }\end{array}$ & 0.007 & 0.006 & 0.016 & 0.011 & 0.011 & 0.015 \\
\hline 9 & $\begin{array}{l}1450- \\
1460\end{array}$ & $\begin{array}{l}\text { Aromatic } \mathrm{C}-\mathrm{H} \\
\text { deformation; } \\
\text { asymmetric in } \mathrm{CH}_{3} \text {, } \\
\text { and } \mathrm{CH}_{2}\end{array}$ & 0.006 & 0.005 & 0.014 & 0.010 & 0.010 & 0.013 \\
\hline 10 & $\begin{array}{l}1510- \\
1520\end{array}$ & $\begin{array}{l}\text { Aromatic } \mathrm{C}=\mathrm{C} \\
\text { stretch from aromatic } \\
\text { lignin }\end{array}$ & 0.004 & 0.003 & 0.010 & 0.004 & 0.006 & 0.009 \\
\hline 11 & $\begin{array}{l}1600- \\
1610\end{array}$ & $\begin{array}{l}\text { Aromatic skeletal } \\
\text { vibration plus } \mathrm{C}=0 \\
\text { stretch }\end{array}$ & 0.006 & 0.004 & 0.010 & 0.009 & 0.006 & 0.012 \\
\hline 12 & $\begin{array}{l}1630- \\
1640\end{array}$ & $\begin{array}{l}\text { Absorbed } \mathrm{O}-\mathrm{H}, \\
\text { Conjugate } \mathrm{C}=\mathrm{O} \text {, } \\
\text { ketone }\end{array}$ & 0.005 & 0.002 & 0.007 & 0.005 & 0.003 & 0.008 \\
\hline
\end{tabular}




\begin{tabular}{|c|c|c|c|c|c|c|c|c|}
\hline \multirow{2}{*}{$\begin{array}{l}\text { Band } \\
\text { no. }\end{array}$} & \multirow{2}{*}{$\begin{array}{l}\text { Band } \\
\text { Region in } \\
\text { Wave } \\
\text { number } \\
\left(\mathrm{cm}^{-1}\right)\end{array}$} & \multirow[t]{2}{*}{ Assignments } & \multicolumn{6}{|c|}{ Relative absorbance } \\
\hline & & & Untreated & $\mathrm{Ph}$ & $\mathrm{SH}$ & $\begin{array}{l}\mathrm{SH}+ \\
\mathrm{Ph}\end{array}$ & PA & $\begin{array}{l}\mathrm{PA}+ \\
\mathrm{Ph}\end{array}$ \\
\hline 13 & $\sim 1705$ & $\begin{array}{l}\mathrm{C}=0 \text { stretch } \\
\text { unconjugated ketone, } \\
\text { esters in xylan }\end{array}$ & 0.002 & 0.001 & 0.003 & 0.001 & 0.002 & 0.005 \\
\hline 14 & $\begin{array}{l}2900- \\
2910\end{array}$ & $\begin{array}{l}\text { C-H stretching, from } \\
\text { methyl, methylene } \\
\text { groups }\end{array}$ & 0.004 & 0.002 & 0.008 & 0.010 & 0.006 & 0.011 \\
\hline 15 & $\begin{array}{l}3300- \\
3400\end{array}$ & $\begin{array}{l}\mathrm{O}-\mathrm{H} \text { vibration from } \\
\text { aromatic and } \\
\text { aliphatic groups }\end{array}$ & 0.009 & 0.005 & 0.017 & 0.014 & 0.013 & 0.017 \\
\hline
\end{tabular}

The peak intensities of $1000-1250 \mathrm{~cm}^{-1}$ can be recognized to contributions of cellulose and hemicellulose having maxima at $1040 \mathrm{~cm}^{-1}$, due to $\mathrm{C}-0$ stretching and $1165 \mathrm{~cm}^{-1}$ due to the asymmetrical C-O-C stretching. The band absorption at $1247 \mathrm{~cm}^{-1}$ is due to $\mathrm{C}-\mathrm{O}$ stretching and this absorption region show feature of hemicellulose and lignin (Fig. 1). The band at $1247 \mathrm{~cm}^{-1}$ indicates elimination of hemicellulose as compared to untreated wood. The band intensity for Ph pretreatment had the lowest value. FTIR analysis indicates that maximum solubilization of hemicellulose and lignin is allocated to Ph pretreatment.

The region of $1400-1460 \mathrm{~cm}^{-1}$ reveals aromatic skeleton $\mathrm{C}-\mathrm{H}$ plane deformations in lignin. For, $1500-$ $1650 \mathrm{~cm}^{-1}$ is similarly included aromatic skeletal vibrations. The lowest absorbance values are reported for $\mathrm{Ph}$ pretreatment. In the wavenumber of $1500 \mathrm{~cm}^{-1}$, the lowest value allocated to $\mathrm{Ph}$ pretreatment as compared to the others. According the results, it is suggested that addition of $\mathrm{Ph}$ to spruce wood causes more lignin changes as compared to the other pretreatments. This results are consistent to the results obtained from acid hydrolysis (Table 1) in which the lignin removal had the highest value for $\mathrm{Ph}$ pretreatment.

The crystallinity index is one of the key parameters to be considered during enzymatic hydrolysis. Hence, the crystallinity index was evaluated based on CLL, LOI, and HBI. Generally, increased CLL, LOI and HBI values represent the highest degree of crystallinity and a more ordered cellulose structure. While decreasing these values designate the amorphous structure of cellulose (Khedkar et al. 2018). Table 3 summarizes the values of different crystallinity ratios (CLL, LOI and $\mathrm{HBI}$ ). 
Table 3

Infrared crystallinity ratio of untreated and treated samples of

spruce wood.

\begin{tabular}{|lllllll|}
\hline Index & \multicolumn{6}{l}{ Relative absorbance } \\
\cline { 2 - 7 } & Untreated & Ph & SH & SH+Ph & PA & PA+Ph \\
\hline CLL & 0.72 & 0.98 & 1.09 & 0.56 & 1.12 & 0.81 \\
\hline LOI & 0.64 & 0.58 & 0.67 & 0.65 & 0.62 & 0.70 \\
\hline HBI & 0.85 & 0.53 & 0.73 & 0.85 & 0.72 & 0.78 \\
\hline
\end{tabular}

$\mathrm{CLL}$ value of the sample treated with $\mathrm{SH}+\mathrm{Ph}$ decreased as compared to untreated sample. In reverse, for other pretreatments, CLL values were higher than untreated sample. This reflects an abundance in lignin with condensed and cross-linked G-type lignin structures. One explanation could be that lignin is solubilized during the pretreatment and then repolymerized/recondensed (Auxenfans et al. 2017). Auxenfans et al. (2017) used steam explosion pretreatment combined with dilute sulfuric acid on spruce wood. Their results showed that CLL values of the treated spruce samples were not statistically different compared to the untreated ones. According Table 3, the lowest and highest LOI values were obtained for $\mathrm{Ph}$ and $\mathrm{PA}+\mathrm{Ph}$, respectively. $\mathrm{HBI}$ of the all pretreated samples were lower than untreated sample (except $\mathrm{SH}+\mathrm{Ph}$ which was equal to it). This indicates decreased crystallinity and increased amorphous cellulose structure of spruce wood which increases the enzymatic efficiency.

\section{SEM Analysis}

The morphological changes of the untreated and treated spruce woods in two magnitudes of 200 and $20 \mu \mathrm{m}$ were evaluated using SEM analysis (Fig. 2). The SEM image of untreated sample indicated an intact surface with well-arranged structure of cellulose, hemicellulose, and lignin (Fig. 2a). After treating with $\mathrm{Ph}, \mathrm{SH}$ and $\mathrm{SH}+\mathrm{Ph}$, the surface layer of spruce wood was destructed (Fig. 2b, $\mathrm{c}$ and d). That's reason is that the pretreatment removes the amorphous cellulose and hemicellulose from inner part. According SEM image, $\mathrm{SH}+\mathrm{Ph}$ pretreatment caused the lignin re-deposition on the biomass surface. This created a corrugated surface for the wood and could result to accelerate in the enzymatic hydrolysis process. The result of CLL concurs with SEM analysis for SH + Ph so that CLL value for this pretreatment had the lowest value (0.560). Moreover, in Fig. 2e, when using PA pretreatment, the morphology of wood did not change. But, using PA + Ph, the morphology of wood demonstrated tiny destruction (Fig. 2f). This result is also consistence with conformational analysis (Table 1) and CLL. As given in Table 1, the lignin removal for Ph and PA were 42.362 and $1.580 \%$, respectively. When $\mathrm{Ph}$ is mixed with PA, caused to arise lignin removal from 1.580 to $6.112 \%$ for spruce sample. In addition, from Table 3 is inferred that with mixing $\mathrm{Ph}(\mathrm{CLL}=0.976)$ and PA $(C L L=1.118)$, the $\mathrm{CLL}$ of the sample reduces to 0.813 .

Summarizing the results of performed analysis in this research demonstrate that among five different pretreatments, Ph represented the best effect on restructuring the spruce wood. Generally, for 
restructuring lignocellulose materials, in previous researches were focused on the effect of alkali, acid and oxidizer chemicals as pretreatments. Ph used as an oxidizer pretreatment in those studies has environmental hazards because of its toxicity. In this study, in order to reducing Ph toxicity, the effect of the combinations of $\mathrm{Ph}$ with alkali and acidic pretreatments on structural change of spruce wood compared to single pretreatments was investigated. The results obtained from LOI and CLL showed that mixing $\mathrm{Ph}$ to $\mathrm{SH}$ caused to increase the structural change of spruce wood as compared to individually use of SH. It can be make easier for enzymes to attack and diffuse into the cellulosic structure of spruce wood. The results of SEM analysis confirmed these results. In mixing $\mathrm{Ph}$ with acidic pretreatment was obtained similar results. Combining Ph with PA led to an increase in PA power in changing structure of spruce wood. This is also well inferred from the results of SEM analysis. After Ph, comparing the obtained results indicates that the combination of $\mathrm{Ph}$ with $\mathrm{SH}$ is more effective compared to the mix of $\mathrm{Ph}$ and PA in terms of changing structure of spruce wood. In addition, between two alkali (SH) and acidic (PA) pretreatments studied in this research, $\mathrm{SH}$ pretreatment represents more structural change in spruce wood.

\section{Conclusions}

Due to the severe nature of lignocellulose biomass, their biodegradability and consequently biogas production is always difficult. In present study, hydrothermal-chemical pretreatments were applied to achieve an efficient lignin removal and structural changes of spruce wood. Alkali, acidic and oxidizer pretreatments were used individually as well as the combination of oxidizer with acidic pretreatment and oxidizer with alkali pretreatment. The results were summarized as follows:

All chemical pretreatments including: $\mathrm{Ph}, \mathrm{SH}, \mathrm{PA}, \mathrm{Ph}+\mathrm{SH}$ and $\mathrm{Ph}+\mathrm{PA}$ change the wood structure and prepare them for digestion.

Among all of the investigated pretreatments, $\mathrm{Ph}$ is more effective on changing the crystalline structure of spruce wood than the others. The amount of lignin removal obtained by $\mathrm{Ph}$ was $42.362 \%$ that is very high compared to the other chemicals not only in current study but also previous researches.

- Combining Ph and PA, causes to rise their effect on lignin removal from $1.580 \%$ to $6.112 \%$. Moreover, combining $\mathrm{Ph}$ and $\mathrm{SH}$ represents the same trend in changing structure of spruce wood as compared to individually use of $\mathrm{SH}$. In other words, adding $\mathrm{Ph}$ improves the biodegradability power of PA and $\mathrm{SH}$.

- After Ph, pretreatment of $\mathrm{Ph}+\mathrm{SH}$ is more effective compared to the $\mathrm{Ph}+\mathrm{PA}$ on structural changes of spruce wood.

- Alkali pretreatment (SH) represents more structural change in spruce wood than acidic (PA) one.

- According the results of current research, it is recommended to use the combination of Ph with SH as infectious pretreatment instead of $\mathrm{Ph}$. Because, this increases the biodegradation power of $\mathrm{SH}$ while the toxicity of Ph decreases. 


\section{Abbreviations}

\begin{tabular}{|ll|}
\hline Symbol & Definition \\
\hline Ph & Phenol \\
\hline SH & Sodium Hydroxide \\
\hline PA & Phosphoric Acid \\
\hline Ph + SH & Combined pretreatments included Phenol and Sodium Hydroxide \\
\hline Ph + PA & Combined pretreatments included Phenol and Phosphoric Acid \\
\hline CLL & Cross-Linked Lignin ratio \\
\hline LOI & Lateral Order Index \\
\hline HBI & Hydrogen Bond Intensity \\
\hline SEM & Scanning Electron Microscopy \\
\hline FTIR & Fourier Transform Infrared \\
\hline ASL & Acid Soluble Lignin \\
\hline AlL & Acid Insoluble Lignin \\
\hline
\end{tabular}

\section{Declarations}

\section{Ethics approval and consent to participate}

Not applicable

\section{Consent for publication}

Not applicable

\section{Availability of data and materials}

The datasets generated and/or analyzed during the current study are available in the [NAME] repository, [PERSISTENT WEB LINK TO DATASETS]

\section{Competing interests}

Not applicable 


\section{Funding}

Not applicable

\section{Authors' contributions}

The Corresponding author accepts responsibility for that:

All authors meet the Authorship criteria listed in the Journal Editorial Policies.

\section{Acknowledgements}

Not applicable

\section{References}

1. Auxenfans T, Crônier D, Chabbert B, Paës G (2017) Understanding the structural and chemical changes of plant biomass following steam explosion pretreatment. Biotechnol Biofuels 10(1) 36 doi:

2. Celiktas MS, Kirsch C, Smirnova I (2014) Cascade processing of wheat bran through a biorefinery approach. Energ Convers Manage 84:633-639.

3. Chen X, Gu, Y, Zhou X, Zhang Y (2014) Asparagus stem as a new lignocellulosic biomass feedstock for anaerobic digestion: increasing hydrolysis rate, methane production and biodegradability by alkaline pretreatment. Bioresource Technol 164:78-85.

4. Chojnacka A, Szczęsny P, Błaszczyk MK, Zielenkiewicz U, Detman A, Salamon A, Sikora A (2015) Noteworthy facts about a methane-producing microbial community processing acidic effluent from sugar beet molasses fermentation. PLoS One, 10(5) doi:

5. Dollhofer V, Dandikas V, Dorn-In S, Bauer C, Lebuhn M, Bauer J (2018) Accelerated biogas production from lignocellulosic biomass after pre-treatment with Neocallimastix frontalis. Bioresource Technol 264:219-227.

6. Ehrman T (1994) Standard method for determination of total solids in biomass. In: Chemical Analysis and Testing Task, Laboratory Analytical Procedure, 242. Available via DIALOG. \&rep=rep1\&type=pdf. Accessed 10 April 2020.

7. Gao X, Kumar R, \& Wyman CE (2014) Fast hemicellulose quantification via a simple one-step acid hydrolysis. BioTechnol Bioeng 111(6):1088-1096.

8. He Y, Pang Y, Liu Y, Li X, Wang K (2008) Physicochemical characterization of rice straw pretreated with sodium hydroxide in the solid state for enhancing biogas production. Energ Fuel 22(4):27752781.

9. Hendriks A, Zeeman G (2009) Pretreatments to enhance the digestibility of lignocellulosic biomass. Bioresource Technol 100(1):10-18. 
10. Khedkar MA, Nimbalkar PR, Kamble SP, Gaikwad SG, Chavan PV, Bankar SB (2018) Process intensification strategies for enhanced holocellulose solubilization: Beneficiation of pineapple peel waste for cleaner butanol production. J Clean Prod 199:937-947.

11. Li C, Liu G, Nges IA, Liu J (2016) Enhanced biomethane production from Miscanthus lutarioriparius using steam explosion pretreatment. Fuel 179:267-273.

12. Liqian W (2011) Different pretreatments to enhance biogas production, a comparison of thermal, chemical and ultrasonic methods. Dissertation, Halmstad University.

13. Mann DG, Labbé N, Sykes RW, Gracom K, Kline L, Swamidoss IM, Burris JN, Davis M, Stewart CN (2009) Rapid assessment of lignin content and structure in switchgrass (Panicum virgatum L.) grown under different environmental conditions. BioEnerg Res 2(4):246-256.

14. Mirahmadi K, Kabir MM, Jeihanipour A, Karimi K, Taherzadeh M (2010) Alkaline pretreatment of spruce and birch to improve bioethanol and biogas production. BioResources 5(2):928-938.

15. Mohsenzadeh A, Jeihanipour A, Karimi K, Taherzadeh MJ (2012) Alkali pretreatment of softwood spruce and hardwood birch by $\mathrm{NaOH}$ /thiourea, $\mathrm{NaOH} /$ urea, $\mathrm{NaOH} /$ urea/thiourea, and $\mathrm{NaOH} / \mathrm{PEG}$ to improve ethanol and biogas production. J Chem Technol Biot 87(8):1209-1214.

16. Monlau F, Barakat A, Trably E, Dumas C, Steyer JP, Carrère H (2013) Lignocellulosic materials into biohydrogen and biomethane: impact of structural features and pretreatment. Crit Rev Env Sci Tec 43(3):260-322.

17. Nelson ML, O'Connor RT (1964) Relation of certain infrared bands to cellulose crystallinity and crystal latticed type. Part I. Spectra of lattice types I, II, III and of amorphous cellulose. J Appl Polym Sci 8(3):1311-1324.

18. Nimz HH (1984) Wood-chemistry, ultrastructure, reactions. Holz Roh Werkst 42(8):314-314.

19. Oh SY, Yoo DI, Shin Y, Seo G (2005) FTIR analysis of cellulose treated with sodium hydroxide and carbon dioxide. Carbohyd Res 340(3):417-428.

20. Pal S, Joy S, Trimukhe KD, Kumbhar PS, Varma AJ, Padmanabhan S (2016) Pretreatment and enzymatic process modification strategies to improve efficiency of sugar production from sugarcane bagasse. 3 Biotech, 6(2), 126. doi:.

21. A. Per (1993) Composition and structure of cell wall polysaccharides in forages. In: Jung HG, Buxton DR, Hatfield RD, Ralph J (eds) Forage cell wall structure and digestibility, ASA, CSSA, SSSA, Madison, pp 183-199.

22. Rajput AA, Visvanathan C (2018) Effect of thermal pretreatment on chemical composition, physical structure and biogas production kinetics of wheat straw. J Environ Manage 221:45-52.

23. Sambusiti C (2013) Physical, chemical and biological pretreatments to enhance biogas production from lignocellulosic substrates. Dissertation, Politecnico Di Milano.

24. Taherdanak M, Zilouei H, Karimi K (2016) The influence of dilute sulfuric acid pretreatment on biogas production from wheat plant. Int J Green Energy 13(11):1129-1134. 
25. Venturin B, Bonatto C, Damaceno FM, Mulinari J, Fongaro G, Treichel H (2019) Physical, chemical, and biological substrate pretreatments to enhance biogas yield. In: Treichel H, Fongaro $\mathrm{G}$ (eds) Improving biogas production. Biofuel and Biorefinery Technologies, vol 9. Springer, Cham, pp 25-44.

26. Zilouei H, Taherdanak M (2015) Biohydrogen from lignocellulosic wastes. In: Karimi K (ed) Lignocellulose-based bioproducts. Biofuel and biorefinery technologies, vol 1. Springer, Cham, pp 253-288.

\section{Figures}

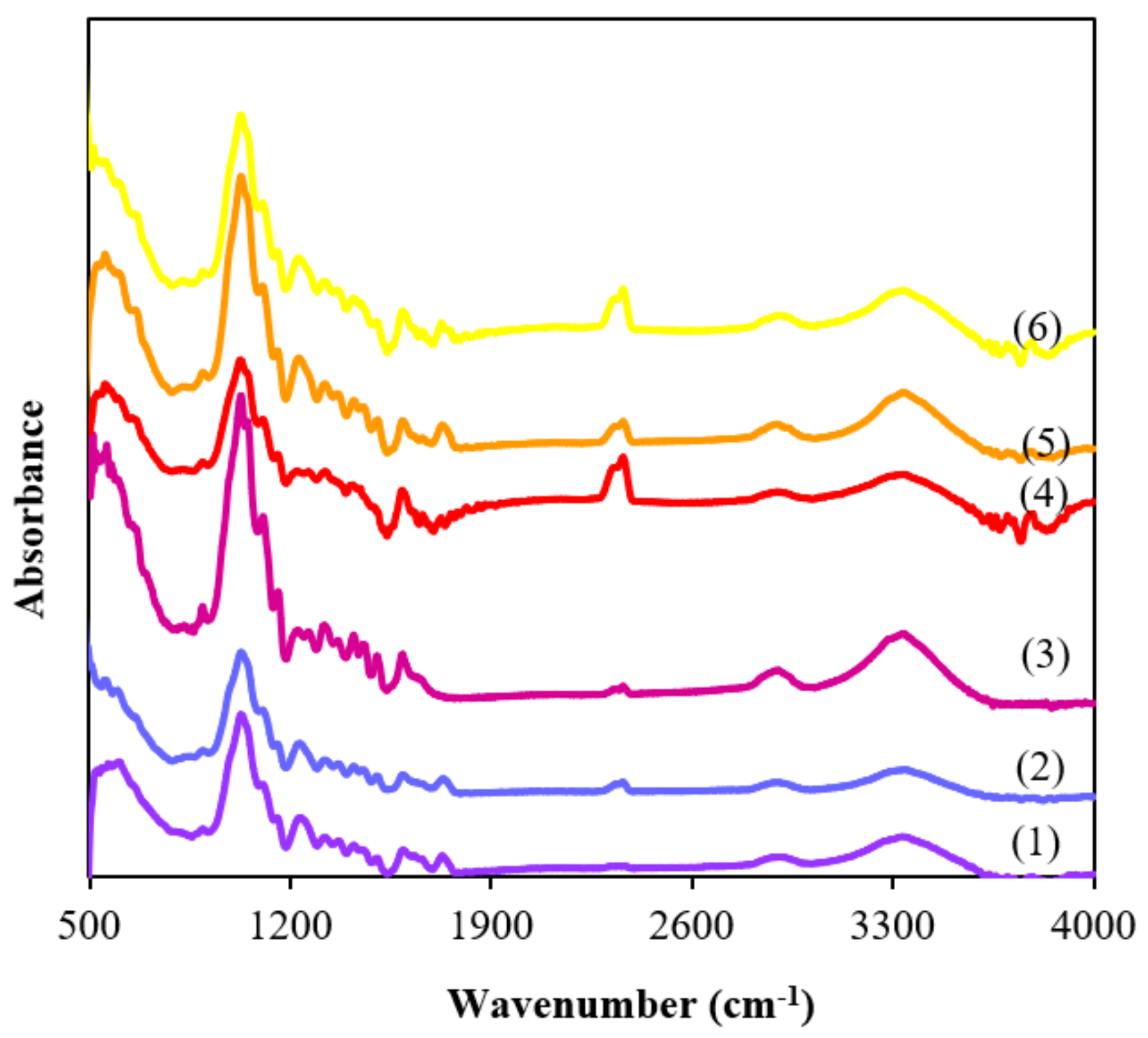

Figure 1

FTIR spectrum of untreated spruce wood (-1) and treated with $\mathrm{Ph}(-2), \mathrm{SH}(-3), \mathrm{Ph}+\mathrm{SH}(-4), \mathrm{PA}(-5)$ and PA $+\mathrm{Ph}(-6)$ 

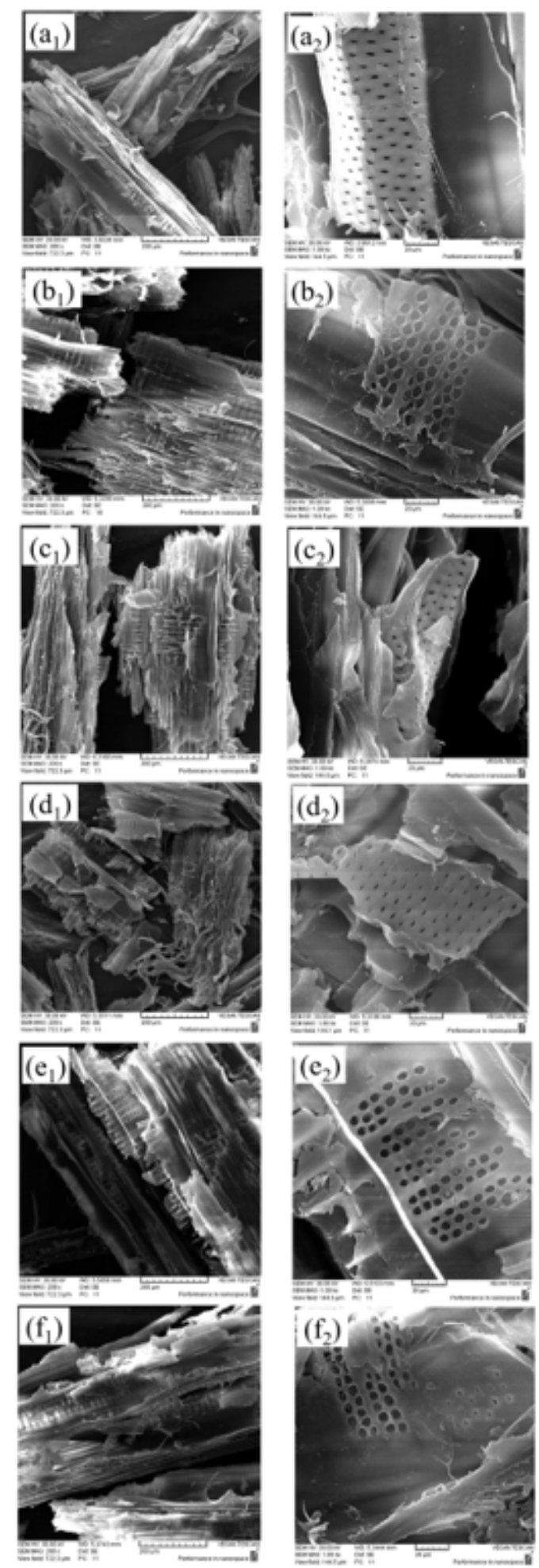

Figure 2

SEM images of spruce woods in two magnitudes of 200 (left) and $20 \mu \mathrm{m}$ (right). (a1,2) untreated sample, $(\mathrm{b} 1,2)$ treated using $\mathrm{Ph},(\mathrm{c} 1,2)$ treated using $\mathrm{SH},(\mathrm{d} 1,2)$ treated using $\mathrm{SH}+\mathrm{Ph},(\mathrm{e} 1,2)$ treated using $\mathrm{PA}+\mathrm{Ph}$

\section{Supplementary Files}


This is a list of supplementary files associated with this preprint. Click to download.

- graphicalabstract.jpg 